International Journal on Integrating Technology in Education (IJITE) Vol.4, No.1,March 2015

\title{
A Phenomenological Study Of Pre-Service TEACHERS REGARDING 21st CENTURY TECHNOLOGY INTEGRATION TRAINING
}

\author{
Christopher Clark Ed.D. ${ }^{1}$ and Dawn D. Boyer, Ph.D. ${ }^{2}$ \\ ${ }^{1}$ Robeson County Public Schools,NC,USA \\ ${ }^{2}$ D. Boyer Consulting,Virginia Beach,VA,USA
}

\begin{abstract}
The purpose of this transcendental phenomenological study was to understand how in-service teachers with 3-5 years of experience perceived their pre-service training regarding integration of $21^{\text {st }}$ Century technology into instruction. Twenty participants from a rural public school system in southeast North Carolina participated. This study attempted to describe: How do $3^{\text {rd }}-5^{\text {th }}$ year teachers in one public school district in North Carolina describe college experiences with educational training to integrate $21^{\text {st }}$ Century technology into their classroom lesson plans? Through interviews and a focus group themes were identified through the participant's perceptions of the phenomena of $21^{\text {st }}$ Century technology integration training. Participants identified these themes: (a) exposure to basic uses of technology, (b) $21^{\text {st }}$ Century technology assignments were neither purposeful nor rigorous, and (c) the majority of integration of confidence and/or competence began after field placements. Themes were used in developing a list of best practices as articulated by the participants.
\end{abstract}

\section{KEYWORDS}

Train-the-teacher, best practices, pre-service technology training, technology integration, traditional licensure training

\section{INTRODUCTION}

A survey by the National Center for Educational Statistics found fewer than half of 3,000 teachers surveyed used technology often during instruction (Gray, Thomas, \& Lewis, 2010). Although state standards and NCATE standards for accreditation require teachers to integrate technologies, inadequate training in the use of technology as an instructional tool continues to be a barrier to successful integration of $21^{\text {st }}$ Century technologies (Zhao, 2007).

State, NCATE, and ISTE standards prefer student-centered technology that supports collaboration between teacher and student while improving the traditional teacher-centered approach to teaching, very few teachers employ technology in this manner (Ottenbriet-Leftwich, Glazewski, Newby, \& Ertmer, 2010). Teachers do report they use "technology to facilitate student learning" (Ottenbriet-Leftwich et. al., 2010, p. 1321), but only one-third surveyed stated they "required their students use computers more than a few times a week" (Ottenbriet-Leftwich et al., 2010, p. 1321).

DOI :10.5121/ijite.2015.4101 
International Journal on Integrating Technology in Education (IJITE) Vol.4, No.1, March 2015

When referring to the newly released USA Department of Education's National Education Technology Plan (NETP), Arne Duncan, the U.S. Secretary of Education, stated, "We have an unprecedented opportunity to reform our schools ... we must dramatically improve teaching and learning, personalize instruction and ensure that the educational environments we offer to all students keep pace with the $21^{\text {st }}$ Century" (U.S. Department of Education, 2010). Systemic change requires much more than confidence; university level leaders need to transform training; instead of focusing on teaching $21^{\text {st }}$ Century technology the focus shifts to teaching with the $21^{\text {st }}$ Century technology. Instead of exposing pre-service teachers to $21^{\text {st }}$ Century technologies as tools, these $21^{\text {st }}$ Century technologies should be seen as tools to transform the act of teaching itself.

To integrate technology, teachers must possess requisite technology-based skills, knowledge, abilities, and attitudes (Teclehaimanot, Mentzer, \& Hickman 2011). While research exists to illustrate how often or the kinds of technology employed in classrooms (Pitler, 2011), there is not enough research for best practices in training teachers during pre-service programs to demonstrate how to effectively integrate $21^{\text {st }}$ Century technologies into instruction.

Transcendental phenomenology focuses on the completeness of experience and the search for the essence of experience. Thus the researcher views experience and the actual behavior related to the experience as an "integrated and inseparable relationship of subject/object (Moerer-Urdahl \& Creswell, 2004, p. 6). The researcher engaged in a transcendental process because the researcher sees the phenomenon "freshly, as for the first time" (Moustakas, 1994, p. 34) and is "open to its totality" (Moerer-Urdahl \& Creswell, 2004, p. 6). This transcendental phenomenological study's purpose was to understand how in-service teachers with 3-5 years of experience perceived their pre-service training regarding the integration of $21^{\text {st }}$ century technology after entering their disciplinary field of classroom instruction.

\subsection{Theoretical Framework}

Andragogy, the theory of adult learning, as espoused by Knowles (1980) is one theoretical framework employed while analyzing data and identifying themes. In 1921, a German social scientist, Eugene Rosenstock argued, "adult education required special teachers, special methods, and a special philosophy" (Knowles, Holton, \& Swanson, 1998, p. 59). Reflective learning situations assist a student in understanding learning habits and helps move them toward new understandings of the information presented.

There are five themes inherent in the andragogical adult learning model. For learners, as they grow into adulthood, the following occur: (a) self-concept moves from being a dependent learner to a self-directed one, (b) experience level increases to become an invaluable learning resource, (c) 'readiness to learn' orients itself to developmental tasks related to social roles, (d) timeperspective related to application of knowledge moves from postponed applications to one of immediacy, and focus moves from a subject-centered to a problem centered orientation, and (e) motivation to learn becomes internally driven (Knowles, 1984b, p. 12). The interplay between themes improves understanding of adult learner ability to internalize new content and is invaluable in creating pre-service $21^{\text {st }}$ Century training objectives. 
International Journal on Integrating Technology in Education (IJITE) Vol.4, No.1, March 2015

Technological Pedagogical Content Knowledge (TPCK or TPaCK) is a technology-based, theoretical framework describing a relationship between a teacher's knowledge of technology, pedagogy, and content. TPaCK is derived from Schulman's work (1986) where he theorized teachers need a new knowledge and Pedagogical Content Knowledge (PCK). PCK is defined as the knowledge of pedagogy specific to particular content areas. This knowledge adds to the subject topic to include the "dimension of subject matter knowledge for teaching" (Shulman, 1986, p. 9).

$\mathrm{TPaCK}$ also provides an integrated framework for understanding how technology connects to "content knowledge and knowledge of teaching" (Kereluik, Mishra, \& Koehler, 2010, p. 13). Content Knowledge (CK) is knowledge about a topic to be learned. Pedagogical Knowledge (PK) is knowledge regarding processes and methods of teaching. Technology Knowledge (TK) is knowledge about existing and emerging technologies. Interactions between these specific bodies of knowledge are also important. Pedagogical Content Knowledge (PCK) is knowledge of pedagogy specific to a particular content. Technological Content Knowledge (TCK) is knowledge about how technology and content "influence or constrain one another" (Kereluik et al., 2010, p. 14). Technological Pedagogical Knowledge (TPK) is knowledge on how technology changes the act of teaching and learning. Knowing how participants position new learning of $21^{\text {st }}$ Century technologies within their current knowledge of content and pedagogy will be an important step in identifying exemplary training scenarios.

\section{METHOD}

The transcendental phenomenological approach was employed to define the qualitative aspects of incorporating technologies into one's pedagogy. Following Clark Moustakas's Phenomenological Research Methods (1994) the study included individuals with a common experience, which was invaluable in reporting themes with how pre-service teachers viewed training experiences related to implementation of technology and identifying best practices as articulated by the participants.

\subsection{Site}

The study was conducted in a rural public school system in SE North Carolina using the snowball sampling method during site selection. There are 43 schools within the district classified as either rural $(n=19)$ or small city $(n=24)$ schools. The majority $(81 \%, n=35)$ of these schools are designated as Title I schools per district publications. Creswell (2007) described the purpose of snowball sampling to identify "cases of interest from people who know people who know what cases are information-rich" (p. 127).

Criteria for site selection was predicated on a 3:1 ratio of students per computer, for each school selected, which is slightly below the district average of 2.02:1 (Education First NC School Report Cards, 2011). Per the Education First NC Schools Reports Cards for this district 38 (88\%) of the schools have a ratio of 3:1 students per computer or better. Schools with the required ratio of computers per student were contacted and asked to participate. District level consent and IRB approval was obtained to conduct this study prior to site and participant selection. 


\subsection{Participants}

Intensity sampling was employed in selection of the participants. Intensity sampling means participants are not the ones most likely or least likely to integrate $21^{\text {st }}$ Century technology, but are more or less likely, which essentially eliminated extreme outliers. This participant sampling provided "information-rich cases that manifests the phenomenon intensely, but not extremely" (Creswell, 2007, p. 127).

Polkinghorne (1989) recommends researchers interview between five to twenty-five participants when conducting interview-based research. Twenty classroom teachers with 3-5 years of experience and licensed to teach (completion of an education program at an accredited institution of higher education) were interviewed as a sample group from the identified population. Participants were from six schools, including five elementary and one high school. Four participants $(20 \%)$ were high school and $16(80 \%)$ were elementary school teachers. Participant demographics are found in Table 1 with their pseudonyms.

Table 1 - Participant Demographics.

\begin{tabular}{lclcc}
\hline \multicolumn{1}{c}{ Participant (ID) } & Gender & \multicolumn{1}{c}{ Ethnicity } & Certification & Exp. (years) \\
\hline Abbey & F & Native American & K-6 & 3 \\
Amber & F & Native American & K-6 & 5 \\
Beth & F & Caucasian & K-6 & 3 \\
Billy & M & Caucasian & History (9-12) & 4 \\
Cindy & F & Native American & K-6 & 4 \\
Debbie & F & Native American & K-6 & 5 \\
Heather & F & Caucasian & K-6 & 4 \\
Jamie & F & Caucasian & K-6 & 3 \\
Jill & F & Native American & K-6 & 3 \\
Johnny & M & Native American & Math (9-12) & 4 \\
Kathy & F & Caucasian & K-6 & 3 \\
Kimberly & F & Native American & K-6 & 3 \\
Larry & M & African American & K-6 & 3 \\
Linda & F & Caucasian & History (9-12) & 5 \\
Luke & M & Caucasian & K-6 & 3 \\
Ruth & F & Native American & K-6 & 5 \\
Sally & F & Caucasian & K-6 & 3 \\
Samantha & F & Native American & Math (9-12) & 4 \\
Susan & F & Native American & K-6 & 5 \\
William & M & Caucasian & K-6 & 4 \\
& & & &
\end{tabular}


International Journal on Integrating Technology in Education (IJITE) Vol.4, No.1, March 2015

The researcher ensured the study sample population had completed a traditional, university level, licensure teacher education program to ensure participation in methods and technology courses. Selecting $3^{\text {rd }}$ through $5^{\text {th }}$ year teachers facilitated the understanding of participant perceptions of current pre-service training and preparedness at a university level. Selection criteria ensured selecting individuals who had experienced the phenomena of pre-service training apropos integration of $21^{\text {st }}$ Century technologies into their instruction.

\section{DATA COLLECTION}

This qualitative study used transcendental phenomenological methods to describe pre-service teacher's perceptions of preparedness to integrate $21^{\text {st }}$ Century technology. The researcher is the human instrument (Guba, 1981) that collected data on shared experiences of participants using interviews, and employing a focus group after receiving IRB approval. The phenomena studied, was $21^{\text {st }}$ Century technology integration training during the college of education program. Interviews and a focus group session assisted in the determination of how participants perceived their $21^{\text {st }}$ century technology integration training while pre-service learners.

\subsection{Interviews}

The interview questions (listed below) were designed to elicit data regarding participants' feelings about training they received as pre-service $21^{\text {st }}$ Century technology integration learners. Interview questions were generated from and grounded within existing research literature. Next, content subject matter experts (SMEs) reviewed the interview questions within the arena of technology education training to verify content validity. Lastly, the interview questions were test-piloted with a non-participant to ensure the questions were clear.

Interviews employed the long interview method utilizing an "informal, interactive process, and utilizes open-ended comments and questions" (Moustakas, 1994a, p. 114). Interviews were audio and video recorded and conducted in the participant's individual classroom or in the school's conference room.

\subsection{Technology Training at the Pre-service Level Interview Questions}

1. Describe the kinds of activities and classroom interactions in which you were engaged during your college of education experience that strengthened your capacity to integrate technology.

2. Explain how technology employed by your instructor during your methods and/or technology courses improved your competency in utilizing technologies to teach.

3. Describe a typical assignment in which you were required to design a technologyintegrated curriculum project.

4. In terms of collaboration (interactions with staff and student peers), what were the characteristics of the planning session for the assignment?

5. Describe how field experiences helped develop the ability to integrate technology into your pedagogy.

6. Describe how your student teaching placement assisted in developing technology integration competence. 
International Journal on Integrating Technology in Education (IJITE) Vol.4, No.1, March 2015

\subsection{Focus Group}

A focus group was employed to gain verifiable data. The researcher served as the moderator in the focus group, allowing participants to dynamically interact, while discussing answers to questions (Creswell, 2007).

The focus group questions listed below were subjected to a three-step process in establishing face- and content-validity. First, each of the six focus group questions were generated from and grounded within the existing research literature. The focus group questions were reviewed by content SMEs within the field of technology education training. A pilot group helped to develop the focus questions from a non-experts pool to ensure questions were clear.

One focus group session was held after receiving IRB approval. All participants were invited to attend this session, however only six participants attended.

\subsection{Focus Group Questions}

1. What specific training, courses, or experiences have enabled you to employ technology into your pedagogy methods?

2. In what ways did your college professors utilize technology?

3. In your college education experience, what strategies worked and which did not in attempts at helping you understand technology integration techniques.

4. Is there anything else you would like to add regarding your training?

\section{DATA ANALYSIS}

Bracketing is defined as, "The first step in phenomenological reduction, the process of data analysis in which the researcher sets aside, as far as is humanly possible, all preconceived experiences to best understand the experiences of participants in the study" (Creswell, 2007, p. 235). Bracketing is followed by the first phase of the data-mining, where selected statements are viewed as unique participant's statements to illustrate researched phenomena (Creswell, 2007). When creating this list the researcher methodically considered literal content and number of occurrences for a statement.

The researcher described textural qualities of the phenomena as experienced by the participants, and then employed the methodology of 'horizonalization' to imagine the phenomena in a multiplicity of ways. Horizontilization is creating a listing of statements having "equal value" (Moustakas, 1994, p. 180) the first phase of data mining, in that the selected statements were viewed as unique statements made by participants and were seen to illustrate the researched phenomena. This step required the researcher observe and describe what was seen from the "vantage point of self-awareness, self-reflection, and self-knowledge (Moustakas, 1994, p. 95). In this phenomenological data analysis step, the researcher grouped significant statements into larger units of similar meaning or themes. Redundancy was eliminated and themes were created within units of meaning that indicated significant topics within clustered groups (Creswell, 2007). Finally, the researcher combined textural and structural descriptions into a description of the essence of the studied phenomena. 
International Journal on Integrating Technology in Education (IJITE) Vol.4, No.1, March 2015

\subsection{Composite Textural description}

When participants reflected on their college of education experience for $21^{\text {st }}$ Century technology integration training, they described the experience using the following terms: "just used PowerPoint," "were not engaged," "mostly lecture," and "Microsoft Word." Participants noted professors "simply lectured" or "just used the SMART Board to display notes," or "only used communications technology like Blackboard and email." Exceptions were some participants whom mentioned a software technology by name, "Geometer's Sketchpad," WebQuests," and "SMART Board tools." Significantly, these participants were either mathematics majors or minors and had more exposure to technology usage models.

Participants spoke about assignments experience using statements, "PowerPoint," "present to professors," "lesson plan," "type," "graph," and "teacher website." One participant noted, "I already knew ... PowerPoint," while another stated "I just don't see where it [technology training] really helped..."

There were notable exceptions to participant's expectations for assignments. The following terms were noted in statements, "activities to perform," "construct polygons," "bisect angles," and "geometry come to life." Again, these terms were noted from either mathematics majors or minors participants.

When speaking of college of education experiences, another grouping of terms were clustered. Participants said, "I came well-rehearsed in SMART Board through field experience," "field experience really helped me," and "ideas, websites to use, Story Line online." One participant summarized, when he said, "it was "getting into the classrooms and seeing how technology was used" that helped him more than anything else.

\section{RESULTS}

The research question aimed to discover perceptions of the college of education experience of $21^{\text {st }}$ Century technology integration training by participants. Three themes were identified succinctly representing participant perceptions. These were:

- College professors used only basic technology

- Assignments involving technology use were neither purposeful nor rigorous.

- Participants did not begin to understand how to integrate technology until they began their field experiences and internship.

There were a few notable exceptions to theme one and two findings; however, the majority of participants agreed these themes illustrated their exposure to technology at the collegiate level. 
International Journal on Integrating Technology in Education (IJITE) Vol.4, No.1, March 2015

\subsection{Basic uses of technology}

When participants discussed how professors used technology, most mentioned their professors simply did not use much technology. According to Debbie, "They [professors] just used ... the computer ... PowerPoint for SMART Board lessons ... more or less just PowerPoint."

Similarly Amber noted, "I ... don't recall any ... instructors using a lot of technology to teach ... mostly lecture ... some overhead projectors ..."

Linda's perceptions regarding professor uses of $21^{\text {st }}$ Century technologies were in line with other participants. She spoke of pre-service classroom exposure to $21^{\text {st }}$ Century technologies, “... PowerPoint ... projector ... lecture ... how to make flyers ... stuff on Microsoft Word ... professor-wise, most used PowerPoint, projectors ..."

Billy echoed the same sentiments when he stated, "It was mostly ... retraining on Word ... as far as incorporating technology into an everyday classroom ... talked about and went over PowerPoints ..."

Some focus group participants noted pre-service training did not provide them with technology integration skills they needed. Heather indicated professors didn't employ technology in her training when she stated:

... we only had one SMART Board in the whole college ... in one classroom and the chalk board was around it ... [the professor] ... wrote ... over the SMART Board and then kept going, never touching the SMART Board ... I was like, oh that thing's really cool, what is that?

Larry, a math major, spoke of how he was exposed to more technology integration efforts because his professors used Geometer Sketchpad during methods classes. He stated:

... we had the math-teaching and technology-integrated course ... from that, I was able to utilize ... different math technology... like, Geometer's Sketchpad ... software all about geometry ... to put formulas in and ... build geometric shapes and test ... angles, rotate, flip, and slide and do ... different things ...

Focus group participants felt they were not exposed to exemplary modeling of $21^{\text {st }}$ Century technology integration techniques as a pre-service learner. The most notable exception was Larry, who had a mathematics concentration. Interview participants also reported it was only after visiting classrooms and observing in-service teachers did they develop a sense of how to integrate $21^{\text {st }}$ Century technologies into instruction.

There were notable exceptions regarding this theme. According to Jamie, "We used a lot of the document cameras ... the professors used those. The professors also ... used PowerPoint and ... WebQuests online."

Johnny, who majored in mathematics, spoke of using computer software, while a pre-service $21^{\text {st }}$ Century technology learner, when he stated, “....we used Geometer's Sketchpad sparingly and that was about the only technology that was incorporated." 
International Journal on Integrating Technology in Education (IJITE) Vol.4, No.1, March 2015

William, who seemed to be the most prepared, and employed technologies after college, noted:

So what he [professor] did was ... our computers ... linked to his SMART Board, so that we had the technology on the computers and he created a lesson that showed us the tools ... and created a mock lesson...

The teachers experienced with some degree of technologies modeling had options of taking other coursework using $21^{\text {st }}$ Century technologies. Johnny, a mathematics major, noted his methods teacher used Geometer Sketchpad when teaching geometry units and was exposed to this software when creating lessons.

William seemed to be the most prepared to employ technologies upon garnering his teaching assignment. Of all the participants, William was exposed to more modeling of technologies while a pre-service learner and was expected to create more technology infused lesson plans. William spoke about the preparation he received:

I went to ... liberal arts college ... two semesters of technology classes specifically geared towards educational technology ...the first was a SMART Board course and the second one integrated technology into ... lesson plans.

\subsection{Assignments neither purposeful nor rigorous}

When participants spoke of technology related assignments as pre-service learners they indicated assignments were basic in nature and did not serve to build $21^{\text {st }}$ Century technology integration competence. Participants mentioned working with groups created by convenience (neighbor in next seat), but more often spoke of having to work on projects alone. Assignments consisted mainly of PowerPoint presentations. Rarely were participants, as pre-service teachers, asked to integrate existing knowledge of technology with instruction in significant ways.

Heather spoke of how exposure to technology as a pre-service teacher did not prepare integration into a future teaching assignment. When speaking about a typical assignment she stated:

I had one technology course in college where we had to create a PowerPoint about a vocabulary word of our choice. We had to make it so kids had to interact with it so there would be sounds ... and ... images ... just the one class and then we had to present it to the professors... we never actually got to use it in a classroom...

Sally indicated her assignments utilizing technologies were not related to her future teaching assignment. She did use the math software program to design worksheets for a future class once. Sally had this to say, regarding her 21st Century technology integration assignments:

We had to design a lesson plan based upon ... technology ... different activities-different programs on the computer or the Internet ... to make our lesson plans ... used Microsoft to type the lesson plans ... used Excel to make a graph, a spreadsheet and then we used it to make a graph and then we had to use Geometer's Sketchpad to make our handout, worksheets. 
There were notable exceptions to the findings. Two participants engaged in activities designed so technology began to facilitate the teaching and learning process. Johnny was engaged with specialized software while in his pre-service mathematics courses. He stated, "We had 20 activities to perform on Geometer's Sketchpad ... to list the sequence of steps...had to construct some polygons... and we had to...bisect some angles."

Larry also spoke of using Geometer Sketchpad while in his pre-service program:

...one assignment ... classifying different angles using ... shapes and objects ... in Geometer's Sketchpad, you were able to pull those objects up ... expand those objects ... turn those objects around ... you can implant the degrees and the angles in there ... you could show how this angle was perpendicular to another angle, how it was parallel to another angle ... so that was one assignment that I really enjoyed doing because it made geometry real life.

Participants were taught and directed to employ technologies, but the requirement to do so did not rise to the standard of true integration within their pre-service education. Twenty-first Century technology integration means using technology to facilitate instruction and change the content or context of teaching, learning and assessing. Utilizing technology simply to satisfy a requirement seemed to characterize $21^{\text {st }}$ Century technology-related, participant pre-service, training assignments.

\subsection{Importance of field experiences and internships}

Participants did not have the integration of $21^{\text {st }}$ Century technology modeled for them during their methods and technology courses. They created lesson plans including legacy (Pre-21 ${ }^{\text {st }}$ Century) technology and designed PowerPoint presentations. All participants stated, once they began to visit classrooms, their knowledge about how to integrate $21^{\text {st }}$ Century technology increased from observation and participation in student teaching tasking. This theme is illustrated in Amber's response:

...when I did my student teaching...they had SMART Boards ... I hadn't seen until I went into the classroom ... I became well rehearsed in SMART Board through field experience and my student teaching.

Cindy acknowledged how field experiences assisted her in developing $21^{\text {st }}$ Century technology integration confidence and competence when she said:

... the field experiences are really what helped ... got to use the document camera ... hands on ... instead of ... telling me what I needed to do about technology, I was able to use it. When I used the document cam I knew exactly how to do it ... to make it interactive with the SMART Board ...

Jamie reported his internship exposure in the classroom helped him understand how to employ technologies in future teaching assignments. According to Jamie: 
International Journal on Integrating Technology in Education (IJITE) Vol.4, No.1, March 2015

... that [field experience and internship] probably helped [me] more than anything else, because I was able to go into the different classrooms, in different grade levels. I was able to see how they incorporated $21^{\text {st }}$ Century technology ... found ... wonderful resources ... for the SMART Board ... that helped more than anything else; actually getting into the classroom and seeing technology used.

The focus group participants indicated they did not really begin to understand how to connect the $21^{\text {st }}$ Century technology to pedagogy and specific content teaching assignments until they began field placements and internships, as recognized by Beth:

As far as formal training ... internship ... opened the door for me. My teacher was into the SMART Board; she knew it front and back. They had had really good training on it [SMART Board] at their school...that got me familiar with it [SMART Board] so when I got my own ... it was ... easy.

Participants had not been exposed to lessons in methods and or technology classes enabling them to see employment of $21^{\text {st }}$ Century technologies as a tool to teach. This point was echoed by Susan when she responded, '... it was mostly ... just lecture; except for the online classes ... Blackboard was really the only technology that I had, which was during (pre-service) online classes..."

This finding was evident in the focus group discussion as well. Five of the participants noted it was during their field placement and internship when they began to understand how to integrate the $21^{\text {st }}$ Century technology into content for lesson plans. This can be summed up in the responses by Larry, "I'd have to say my student teaching experience was the most beneficial to me," and by Linda, “... I learned about technology ... through my student teaching."

Larry participated in the focus group session and was the only participant exposed to modeling of software and technology during pre-service training. Larry had achieved a minor in mathematics and spoke of his methods teacher using Geometer Sketchpad often.

Participants were exposed to education-related technology used to display notes or as an assist to presentations. Linda noted, “... it was just PowerPoint and projector, not really anything else...lecture..." when she explained how technology was used in pre-service training. Participant's noted their pre-service assignments requiring the use of technology did not serve the purpose of helping them understand how to employ $21^{\text {st }}$ Century technologies into future learning plans. This is exemplified by Amber, “...I know we were trained on teacher websites ... on how to do a teacher website, but ... I can't recall ... other ways we were taught to incorporate technology into the classroom."

Participants indicated modeling is a powerful tool when used to integrate technologies. However, most participants were not exposed to this during their college education experience, as noted in the following statements, "they used PowerPoint," "mostly lecture," and "making flyers ... on Microsoft Word." A few participants, who were either mathematics majors or minors, were exposed to other software modeling.

Reflecting back, most participants noted assignments lacked a training purpose and rigor, demonstrated by statements such as, "we had to create a PowerPoint," "it didn't really help me," 
International Journal on Integrating Technology in Education (IJITE) Vol.4, No.1, March 2015

and "we never actually got to use it in a classroom." One participant noted an exception in describing the use of geometry software to "make geometry come to life."

Finally, participants spoke of how field placements and internships assisted them, "I came wellrehearsed in SMART Board through field experience," "I was able to use it [technology]," and "that [field experience] probably helped [me] more than anything."

When describing training as pre-service teachers, nearly all participants reported they were not trained to integrate $21^{\text {st }}$ Century technology into lesson plans. They spoke of how college instructors rarely employed technologies to teach them, except for basic methodology (PowerPoint to display notes, using email and or Blackboard systems to communicate). One participant was trained to use a SMART Board, and provided a series of lessons to use, once teaching. He had options when selecting technology courses during his course of study. Four participants used Geometer Sketchpad during their coursework and were either mathematics majors or minors.

Participants were not required to utilize technologies in authentic ways or methodologies as preservice learners. Pre-service assignments were not easily transferrable to post-hire classroom settings requiring integration $21^{\text {st }}$ Century technologies. For example, assignments involved the participants creating a PowerPoint for a classroom presentation or mentioning how $21^{\text {st }}$ Century technology would be used in a lesson plan. Pre-service learners were not learning-focused on employing technology as a tool to facilitate teaching and to transform classroom dynamics.

Exceptions did exist within the responses. Two participants had to create WebPages, one created a WebQuest, and two others created virtual field trips. One participant spoke of a virtual field trip regarding the Underground Railroad that allowed students a choice of 'knocking' on a virtual door to ask for 'safe harbor.' She reported student engagement increased using this $21^{\text {st }}$ Century technology.

Finally participants as pre-service learners began to understand how to employ $21^{\text {st }}$ Century technologies when they began field placements and internships. The dominant theme was participants were exposed to technology modeling by practicing teachers. This modeling of the $21^{\text {st }}$ Century technology situated the use of $21^{\text {st }}$ Century technology within the participant's instructional context.

\section{SYNTHESIS OF THE COMPOSITE TEXTURAL AND COMPOSITE STRUCTURAL DESCRIPTIONS}

When describing technology training received as pre-service teachers, nearly all participants reported no training on how to integrate $21^{\text {st }}$ Century technology into instruction. They repeatedly spoke of how college instructors rarely employed technologies to teach. When professors used the technology, it was for basic uses such as notes (PowerPoint visual), email (digital communication), or Blackboard (classroom management system, for class content management and grading assignments for the students. The participant trained to use the SMART Board was provided lessons once he began teaching, so had options when selecting technology courses during his studies. Four other participants used Geometer Sketchpad during their coursework, but were mathematics majors or minors. 
International Journal on Integrating Technology in Education (IJITE) Vol.4, No.1, March 2015

Finally participants as pre-service learners began to understand how to employ 21 st Century technologies when they began their field placements and internships. The overwhelming refrain was the participants were exposed to modeling by practicing teachers. This modeling of the $21 \mathrm{st}$ Century technology situated the use of 21 st Century technology squarely within the participant's instructional context.

\section{IDENTIFICATION OF BEST PRACTICES}

The following best practices attempt to incorporate the core principles of Andragogy as articulated by Knowles (1980) which argue adults: (a) should understand why they need to learn something before being trained, (b) are self-directed learners whose prior-experiences should be taken into account, and (c) are ready to learn when they need to perform a life centered task which builds competence. Participants reported best practices are mindful of the relationship between a teacher's technological pedagogic knowledge (TPK), technological content knowledge (TCK) and technological, pedagogical, content knowledge (TPaCK) (Kereluik et al., 2010). Twenty-first century technology training should begin with exposure to the technology, its characteristics, terminology, and basic uses (TK). Finally, training should then move to helping the learner understand how $21^{\text {st }}$ Century technologies, as a tool to facilitate teaching and learning, can assist in extending and enriching learning activities in the classroom (TPaCK) (Kereluik et al., 2010).

According to participants, the best practices America's colleges of education could adopt to meet the $21^{\text {st }}$ Century technological needs of pre-service teachers as adults, as well as meet TPACK guidelines are:

- Modeling of 21st Century technologies should be pervasive throughout the teacher education program in content and methods courses.

- Pre-service teachers should be provided multiple opportunities to employ technologies as an instructional tool through simulated teaching experiences before service or internship.

- Partnerships between K-12 schools and teacher education programs should be leveraged to expose pre-service teachers to content specific applications of $21^{\text {st }}$ Century technologies during field placements and internships.

When pre-service teachers are afforded opportunities for hands-on applications of technologies in real world contexts, it is demonstrated they develop confidence and competence in utilizing those teaching technologies (Sutton, 2011). When colleges of education follow through on NETS for Teachers and the Essential Conditions from ISTE, important connections are established within K-12 education communities that support teacher candidate exposure to effective technology through field experiences where technology is being integrated (ISTE, 2000b). Jamie spoke of how powerful the modeling and simulated teaching exercises had been for her during her field placements:

Student teaching helped me see the long-term effect of technology ... I could incorporate on a daily basis ... or the student period-student teaching time ... to see how I could integrate it across the curriculum ... that's really how students teaching helped. 
International Journal on Integrating Technology in Education (IJITE) Vol.4, No.1, March 2015

\section{IMPLICATIONS}

A re-development or added curriculum for teaching methodology is highly recommended as the conclusion of this study. Teaching institutions are encouraged to be more receptive to providing curriculum on how to use technologies to enrich content pre-service teaching students are expected teach (Sutton, 2011; Teclehaimanot, Mentzer, \& Hickman, 2011). According to the research study participants, professors used technology for basic functions such as displaying notes and sending emails, but not for teaching in the classroom environment themselves. Technology staff development at the collegiate level should prepare college faculty to model effective uses of current technologies for pre-service teachers to develop competencies for teaching (Angeli \& Valanides, 2008). This can be accomplished by professorial modeling - not only in the methods or technology courses - but, throughout the college experience (Sutton, 2011).

Improving competence and confidence at integrating current technology in pre-service teachers curriculum is dependent on college faculty requiring their students to use technology in simulated teaching experiences (Kumar \& Vigil, 2011). This goes far beyond the requirement to use older technologies for demonstration(s). When college professors are adept at employing the $21^{\text {st }}$ Century technology in pedagogic and content specific ways, they can better assist students in developing their own abilities (Koh \& Frick, 2009).

America's higher education institutions should establish networks with schools and integrate current and future teaching technologies. These connections could then provide a vehicle through which pre-service teachers can experience authentic methods of integrating teaching technology into content they are expected to teach (ISTE, 2000b; Meagher, Ozgun-Koca, \& Edwards, 2011; Sutton, 2011; Teclehaimanot et al., 2011). Technology-rich field placements and internships, according to participants in this study, serve to build confidence and competence in integrating 21st Century technologies.

\section{RECOMMENDATIONS FOR FUTURE RESEARCH}

Twenty-first Century technology integration training builds participant technological content knowledge (TCK), develops participant's pedagogic and content connections (PCK), and helps participants assimilate the technology into what future teachers already know about teaching and learning (TPK) for true $21^{\text {st }}$ Century technology integration to occur (TPACK). Further research is needed to discover and expand the knowledge of complex interplay between technological pedagogic knowledge (TPK), technological content knowledge (TCK), and pedagogical content knowledge (PCK) to identify best practices for developing pre-service teacher technology integration competence and confidence.

There has been little research concerning best practices in training adults on how to integrate current and future technologies into teaching. This study has shown continued research in this area can yield insights into how adults learn to employ $21^{\text {st }}$ Century technologies. State and or national level studies should be conducted so $21^{\text {st }}$ century technology integration pre-service teacher training can be understood from an adult perspective within wider contexts. Close examination of these experiences may promote change within teacher education programs from the current methodology centered approach to teaching twenty-first century technology integration to one more attuned to the needs of the adult learner. 
Another recommendation would be to look further into the differences between preparation programs. Do mathematics and science methods and content professors use more technologies when teaching compared to other disciplines? Is it easier for elementary education majors to integrate technologies? To what extent are professor uses of technologies aligned with NETS for teachers? Participants noted the lack of modeling by their college of education professors, so more research seems warranted to confirm their observations. Participants noted field placements and internships helped them understand how to integrate $21^{\text {st }}$ Century technology, so additional research is suggested to understand how and why this was observed.

\section{CONCLUSION}

Participants noted they needed the college of education experience to provide them with authentic, relevant, and purposeful exposure to $21^{\text {st }}$ Century technologies. This can be accomplished by ensuring college faculties model teaching-centric technology within the curriculum of teaching programs. Teachers as pre-service learners should be afforded sufficient opportunities to practice using $21^{\text {st }}$ Century technologies through simulated teaching exercises requiring integration of technology. In conclusion, field placements and internships need to emphasize teachers employing $21^{\text {st }}$ Century technologies as tools to facilitate teaching and learning.

\section{REFERENCES}

1.Gray, L., Thomas, N., \& Lewis, L. (2010). Teachers' use of educational technology in U.S. public schools: 2009 (NCES 2010-040). Washington, DC: National Center for Education Statistics, Institute of Education Sciences, U.S. Department of Education.

2.Zhao, Y. (2007). Social studies teachers' perspectives of technology integration. Journal of Technology and Teacher Education, 15(3), 311-333.

3. Ottenbreit-Leftwich, A. T., Glazewski, K. D., Newby, T. J., \& Ertmer, P. A. (2010). Teacher value beliefs associated with using technology: Addressing professional and student needs. Computers and Education, 55(3), 1321-1335.

4. United States Department of Education, (2010). U. S. Department of Education releases finalized national education technology plan. Retrieved from http://www.ed.gov/news/press-releases/usdepartment-education-releases-finalized-national-education-technology-plan

5. Teclehaimanot, B., Mentzer, G., \& Hickman, T. (2011). A mixed methods comparison of teacher education faculty perceptions of the integration of technology into their courses and student feedback on technology proficiency. Journal of Technology and Teacher Education, 19(1), 5-21.

6.Pitler, H. (2011). So many devices, so little use. T. H. E. Journal, 38(6), 42-44.

7.Moerer-Urdahl, T., \& Creswell, J. W. (2008). Using transcendental phenomenology to explore the "ripple effect" in a leadership mentoring program. International Journal of Qualitative Methods, 3(2), 19-35.

8. Moustakas, C. (1994). Phenomenological research methods. Thousand Oaks, CA: Sage Publications, Inc.

9. Knowles, M. S. (1980). The modern practice of adult education: From pedagogy to andragogy. Englewood Cliff, NJ: Cambridge Adult Education.

10. Knowles, M. S., Holton, E. F., \& Swanson, R. A. (1973). The adult learner. Burlington, MA: Elsevier Inc.

11. Knowles, M. S. (1984b). Andragogy in action. San Francisco, CA: Jossey-Bass.

12.Shulman, L. S. (1986). Those who understand: Knowledge growth in teaching. Educational Researcher, 15(2), 4-14. Retrieved from http://www.jstor.org/stable/3202180 
13. Kereluik, K., Mishra, P., \& Koehler, M. J. (2010, Winter). On learning to subvert signs: Literacy, technology and the TPACK framework. The California Reader, 44(2), 12-18.

14.Education First NC School Report Cards, (2011). Retrieved from http://www.ncreportcards.org/src/search.jsp?pYear=2010-

2011\&pList=1\&pListVal=780\%3APublic+Schools+of + Robeson + Coun \&GO2=GO

15.Creswell, J. W. (2007). Qualitative inquiry \& research design: Choosing among five approaches (2nd ed.). Thousand Oaks, CA: Sage Publications, Inc.

16. Guba, E. G. (1981). Criteria for assessing the trustworthiness of naturalistic inquiries. Educational Technology Research \& Development, 29(2), 75-91.

17. Sutton, S. R. (2011). The pre-service technology training experiences of novice teachers. Journal of Digital Learning in Teacher Education, 28(1), 39-47.

18. International Society for Technology in Education (ISTE). (2000b). NETS for teachers 2000 essential conditions. Retrieved from www.iste.org/standards/nets-for-teachers.aspx

19. Angeli, C., \& Valanides, N. (2008, March). TPCK in pre-service teacher education: Preparing primary education students to teach with technology. Paper presented at the AERA annual conference, New York.

20.Kumar, S., \& Vigil, K. (2011). The net generation as pre-service teachers: Transferring familiarity with new technologies to educational environments. Journal of Digital Learning in Teacher Education, 27(4), 144-153.

21.Koh, J. L., \& Frick, T. W. (2009). Instructor and student classroom interactions during technology skills instruction for facilitating pre-service teachers' computer self-efficacy. Journal of Educational Computing Research, 40(2), 211-228. doi:10.2190/EC.40.2.d

22. Meagher, M., Özgün-Koca, S. A., \& Edwards, M. T. (2011). Pre-service teachers' experiences with advanced digital technologies: The interplay between technology in a pre-service classroom and in field placements. Contemporary Issues in Technology and Teacher Education, 11(3), 243-270.

\section{Authors}

Christopher Clark, Ed.D., Public Schools of Robeson County, 101 Bryant Road Red Springs, NC 28377, (910) 785-0250, cclark9265@gmail.com; he is an Adjunct Instructor with Liberty University (School of Education) and a high school principal with the Public Schools of Robeson County; He has served as an Assistant Principal, LEA Test Coordinator, and mathe matics teacher for 21 years in public education (corresponding author).

Dawn D. Boyer, Ph.D., D. Boyer Consulting, 5428 Whitehurst Arch, Virginia Beach, VA 23464; (757) 404-8300, Dawn.Boyer@dboyerconsulting.com; she has served as a Information Technology instructor at Old Dominion University, private tutor, and public school teacher for Virginia Beac h City Schools, and currently provides instruction to corporate and private clients as a consultant and publisher (contributing author).
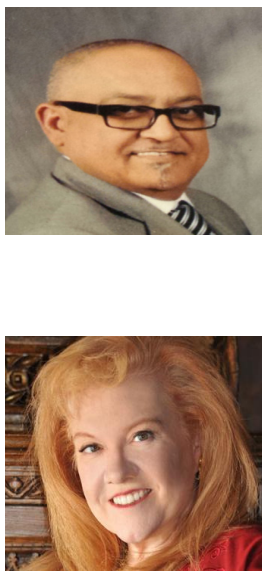